\title{
Designing and Developing A Smart Application for Improving the Communication Between the Deaf, Dumb People and Society
}

Fatimah Mohammed Al Nas, Sajidah Hassan Sahwan, Fatimah Saeed Alali, Muneerah Alshabanah, Daniah Alrajhi, Mutasem K. Alsmadi, Ibrahim Almarashdeh and Mohammed Fahed Tayfour

Department of Management Information Systems, College of Applied Studies and Community Service, Imam Abdulrahman Bin Faisal University, Dammam, Saudi Arabia

\begin{abstract}
Technology and Science have made Human life addictive to luxury but still there exists poor people who are trying to find innovative ways which make the communication process easier. Regarding to the World Health Organization, about 1 million people are dumb and 300 million are deaf in the world. Whereas; the communication is one of the most important issues for deaf and dumb people. This work aims to propose a smart application named "Jusoor" to improve the communication process and bridge the gap between the deaf, dumb People, and society. The proposed application provides the user with a dictionary that contains many vocabularies with videos explaining the way that the word is indicated, the most important sentences used in public places (markets, parks, restaurants, etc.), Emergency calls that enable recognizing the type assistance needed with the feature of locating the person which makes it easier to reach and provide the assistance, and service of communication with sign language experts. The proposed work was analyzed using the Unified Modeling Language (UML), Firebase, XML and Java programming languages.
\end{abstract}

Keywords: Deaf, Dumb, Android Application, Sign Language and Unified Modeling Language.

\section{INTRODUCTION}

The World Health Organization (WHO) stated that about 300 million are deaf, 1 million are dumb and many more are suffering from one or more of the aforementioned physical disabilities. The developments in Science and Technology have reached to great heights in making the Human Life easier and comfortable within a short span of time [1$10]$.

During the few last years, many technologies have made our life more comfortable and easier, even without moving our bodies to do a task. The physically disabled people are part of our community who are deprived from the advancements of
Technology and Science since they need it to feel that they are the part of the society and they can walk hand in hand and participate with others in the community development. Also, Communication is a important issue in the human life especially the people who are Deaf or Dumb $[1-4,6,11]$.

This work aims to propose a smart application named "Jusoor" to bridge the gap and improve the communication process between the deaf, dumb People, and society. The proposed application provides the user with a dictionary that contains many vocabularies with videos explaining the way that the word is indicated, the most important sentences used in public places (markets, parks, restaurants, etc.), Emergency calls that enable 
recognizing the type assistance needed with the feature of locating the person which makes it easier to reach and provide the assistance, and service of communication with sign language experts.

\section{Study Significance}

This proposed application achieves a great positive impact on deaf and dumb people and the rest of society. Where, the proposed application removes the barriers between them, enhances their selfconfidence and makes them feel able to communicate with the community, and performs all their activities without feeling fear of not understanding others, which makes them feel comfortable in Communication. Moreover; the proposed application serves the community in dialogue with this category in public facilities, schools, universities, etc.

For example, shopping through the application allows to communicate with sellers as well as in restaurants when choosing food, sports clubs and others, and helps them to participate in events and celebrations, and allows the delivery of their ideas to society without the need for a person to help them.

\section{Related Works}

\section{- Ihsan Human "إحسان إنسان"}

Ihsan Human "إحسان إنسان" is a mobile phone application that was worked on in Saudi Arabia, an application developed to help the category of people with hearing impairment by converting written words or phonetic phrases into sign language, as the goal of the application is to integrate this category of deaf and dumb with the community and facilitate the process of communication with others [12]. The application contains more than 24 thousand Arabic words converted to the sign language, and the developer intends to introduce other languages and the possibility of converting the sign language from the deaf person into phrasal phrases. Figure 1 below show screenshot of Ihsan Human application.

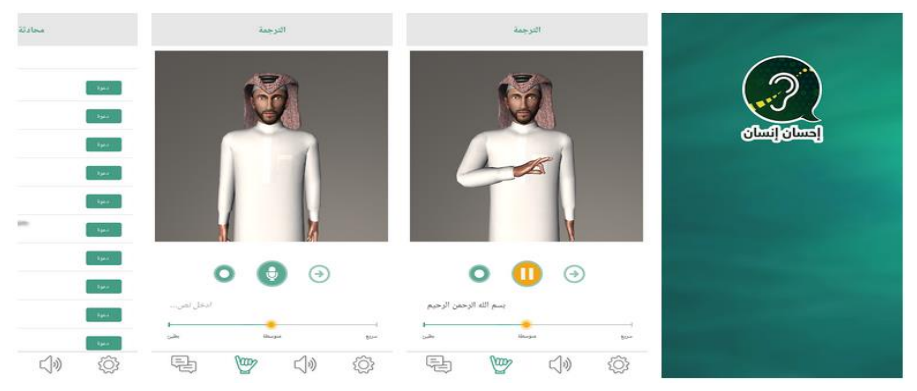

Figure 1: Screenshot of Ihsan Human application.

\section{- Tawasoly " Tواصلي"}

Tawasoly " is an application that serves the urgent need for people with hearing impairment and hearing impairment to communicate with society in an easy and dual way communication, so that the deaf uses a communication application to communicate with the listener by writing words in the Arabic sign language keyboard and then the text will turn into a voice in Arabic [13]. The listener also use the application to communicate with the deaf through the sign language without the need to learn it, as the application will convert the text and voice to the Arabic sign language through 3D animation. Figure 2 below show Screenshot of Ihsan Human application.

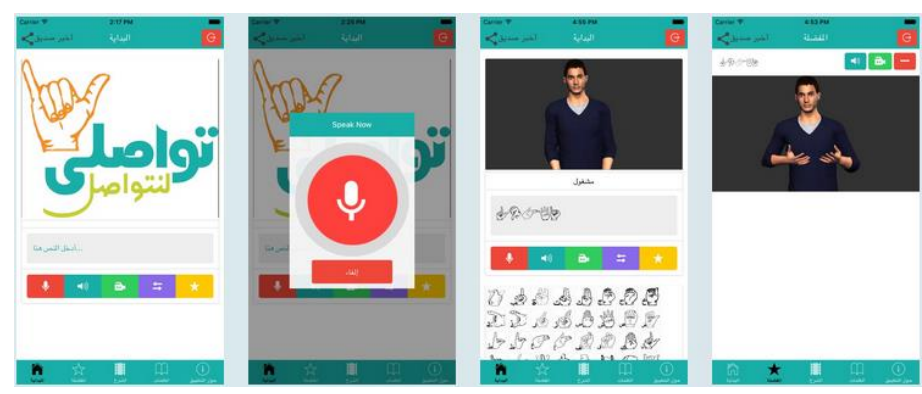

Figure 2: Screenshot of Ihsan Human application.

- $\quad$ "let me Hear you" Application 
This app is designed to help people with hearing disabilities and the hearing impaired to communicate and ask for help in case of emergency [14]. So that the user can touch and ask for help and will automatically determine his/her location and write an author and automatically sent to the security agencies and to persons designated through the application settings, making it easier to reach the user, and provide assistance. The application is simple to use, and boasts several classifications and emergency situations (traffic, police, road safety, ambulance, fire fighting). Figure 3 below show Screenshot of Hear you application.
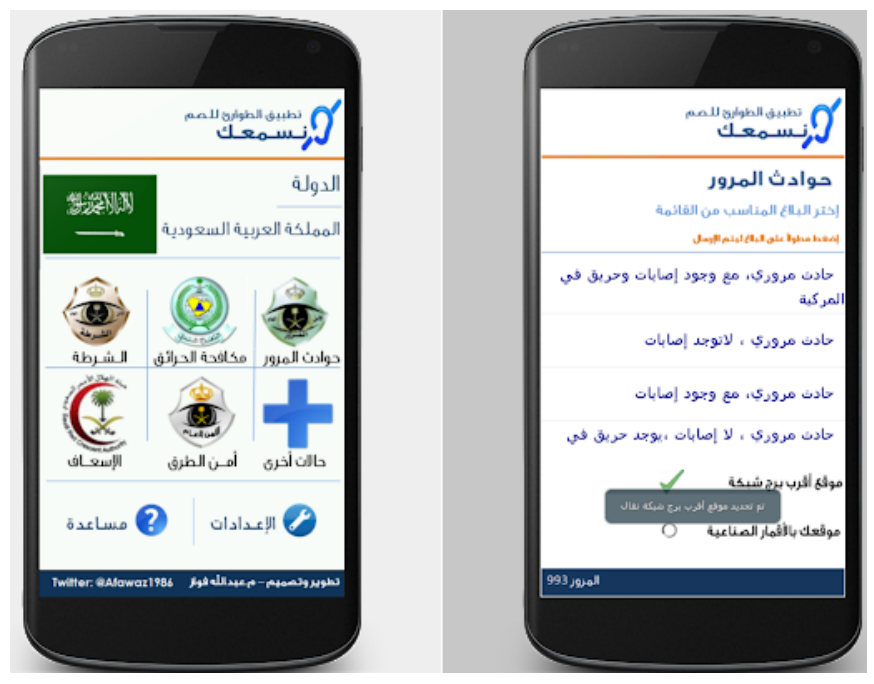

Figure 3: Screenshot of Hear you application.

\section{- AlTurjumanSL}

AlTurjumanSL is an application to translate written and spoken sentences into Arabic sign language through three-dimensional characters at the same moment easily [15]. The application facilitates the process of communicating with the deaf community without the need for the speaker to know the sign language, in addition to the fact that the AlTurjumanSL application is a very effective tool for learning the sign language in a fun and easy way.
Figure 4 below show Screenshot of AlTurjumanSL application.
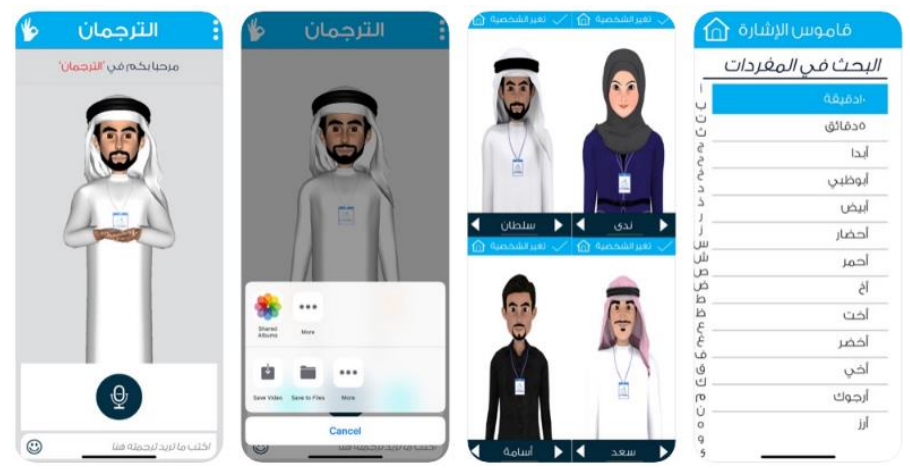

Figure 4: Screenshot of AlTurjumanSL application.

The technological revolution influenced everything [16-93], even the approaches that aim to bridge the gap and improve the communication process between the deaf, dumb People, and society by introducing a free electronic application. Today, the use of Artificial Intelligence (AI) algorithms is expansive, particularly in providing solutions to challenging problems including image segmentation [17], information retrieval [63] and Healthcare Monitoring system [56, 67]. Therefore; many technologists have used $\mathrm{AI}$ as an effective technique for introducing new smart applications to improve the communication process between the deaf, dumb People, and society.

\section{Methodology}

Object-oriented design and analysis offer an approach which facilitates rapid, logical, and detailed methods to create new systems responsive to a changing business landscape. Object-oriented techniques wellfunctioning in situations in which complicated information systems are undergoing continuous adaptation, maintenance, and redesign.

In this work, the unified modeling language (UML) will be used, the industry standard for modeling object-oriented systems. The UML toolset includes 
diagrams that allow to visualize the construction of an object-oriented system.

\subsection{Use Case Diagram}

In UML, use case diagram is a behavior or dynamic diagram. Use case diagrams model the system functionality using use cases and actors. Use cases are a set of services, actions, and functions that is needed by the system to perform. In this context, a "system" is something operated or developed, for example a web site. The "actors" are entities or people operating within the system under defined roles. In the proposed application, the actors are the Normal User, Admin, Deaf User, Visitor and Assistant User. Figure 5 shows the use case diagram for the proposed application.

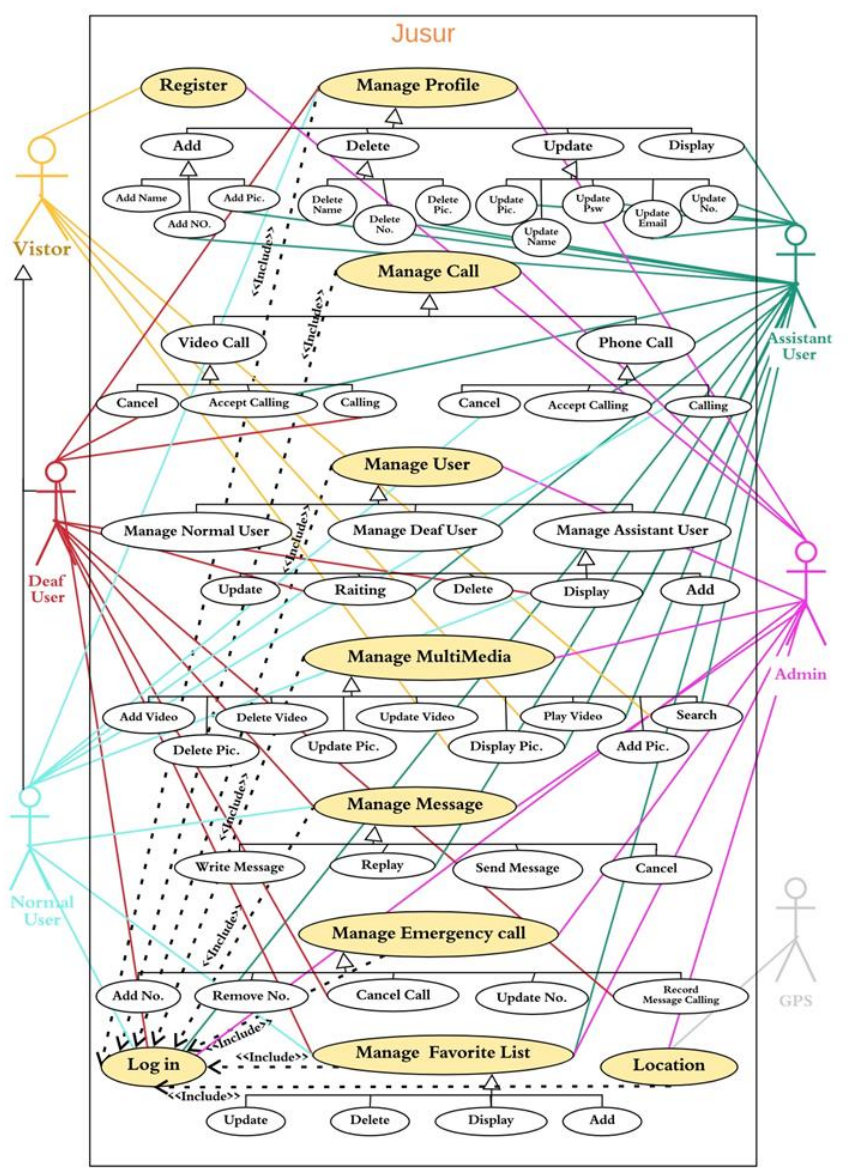

Figure 5: Use case diagram for the proposed application.

\subsection{Context diagram}

A Context Diagram is a simple but robust tool that obviously shows the under consideration system and the external entities which interact with it $[94,95]$. A context diagram shows at a very high level:

- The boundaries of the system

- The external enties - these could be other systems or people

- The information which flows between these external entities and the system

External entities include several systems and stakeholders that have direct interactions with the system under consideration. Figure 6 represents the context diagram of the proposed application.

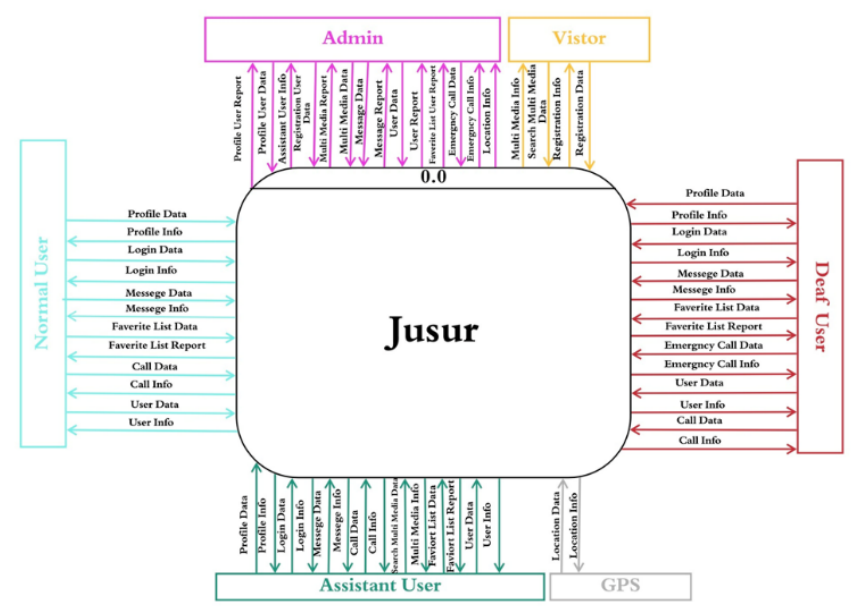

Figure 6: Context diagram of the proposed application.

\subsection{Entity Relationship (ER) Diagram}

An Entity Relationship Diagram (ERD) is a flowchart which shows how "entities" relate to each other within a system [96-102]. ER Diagrams are often used 
to debug or design relational databases in software engineering, education, business information systems and research. Figure 7 shows the ER diagram for the proposed application.

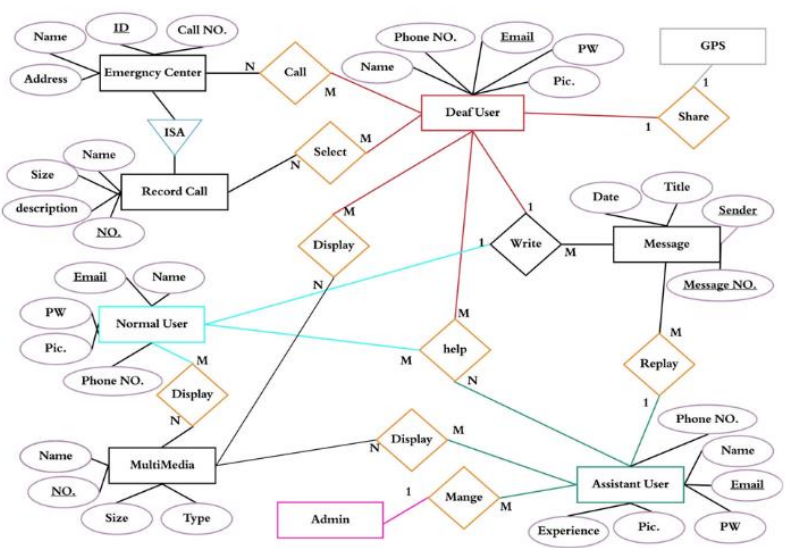

Figure 7: ER diagram for the proposed application.

\section{Interface Design}

Interface Design is the graphical design of the application which consists of the text, button, text entry fields, images, slider, and all the items that users use for interaction. The figures below are examples of the designed interfaces.
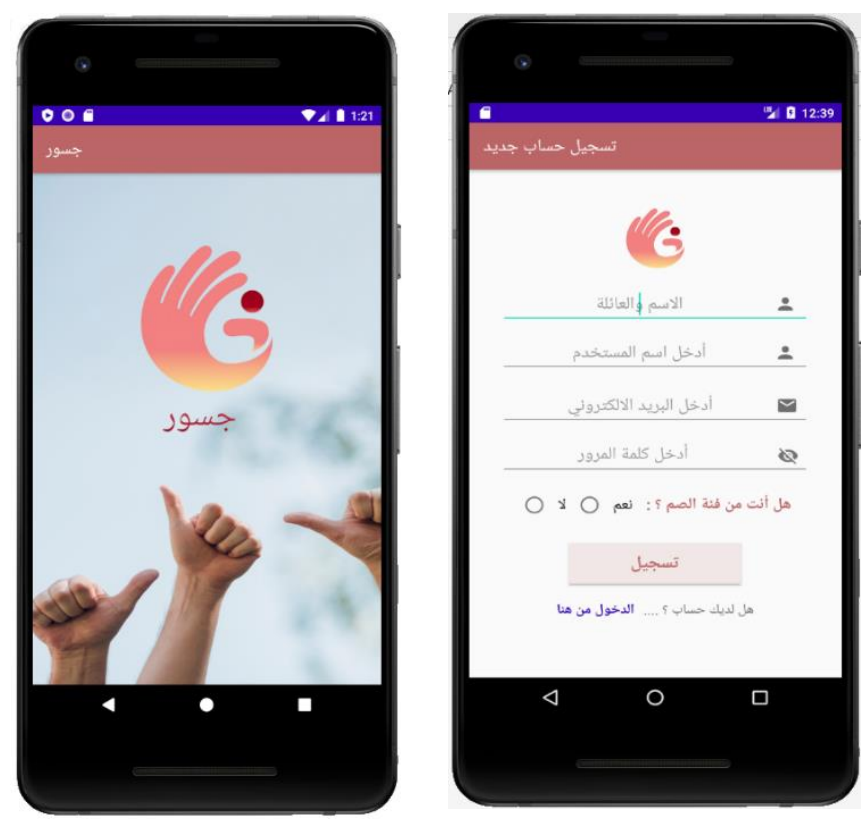

Figure 8: Home page

interface

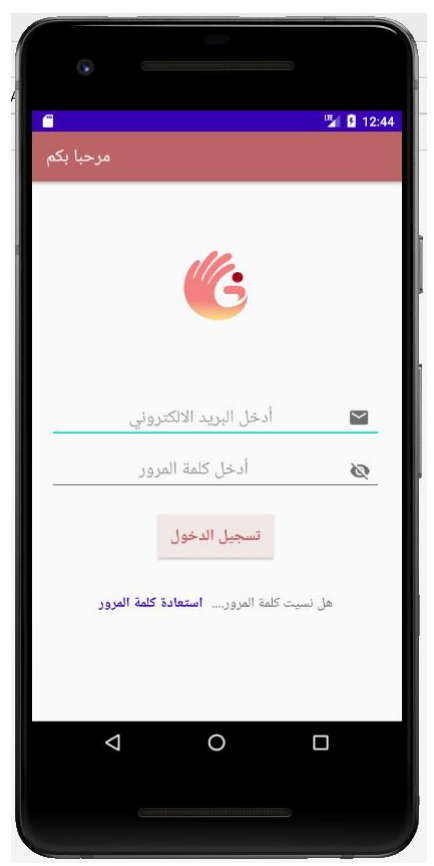

Figure 10: Login interface

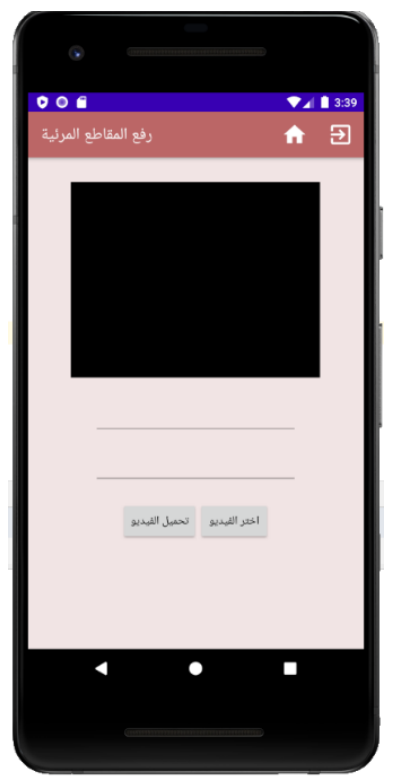

Figure 12: Video upload interface

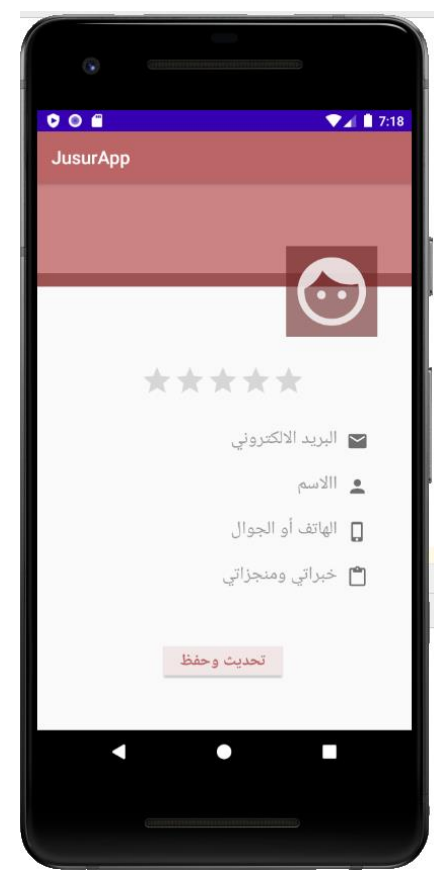

Figure 11: Profile interface

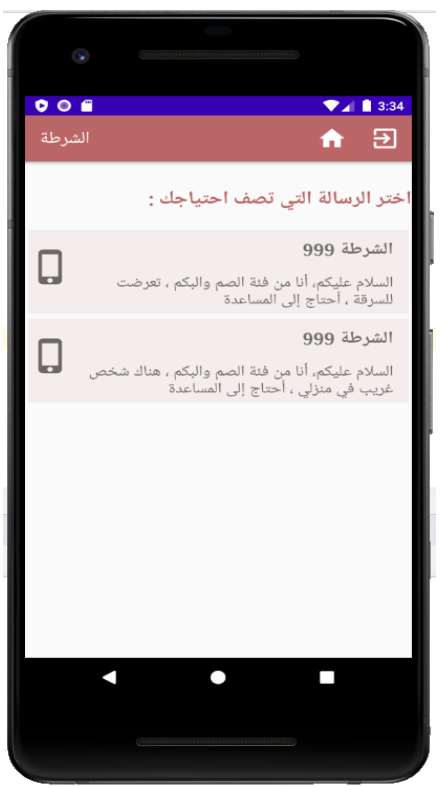

Figure 13: Emergency call interface

\section{Discussion}

Figure 9: Registration interface 
Usability testing is the experimental way for detecting product's user elements and finding the problems which are facing the users. The main goal of testing usability is to evaluate the product usability and evaluate the system, 20 students from the Imam Abdurrahman Bin Faisal University (IAU) from our faculty were invited to use the proposed application. Then the student answered a survey consisting of 10 items for measuring the user satisfaction level (as shows in figure 14). As can be understood from the result, most of the users agree that the system is beneficial, easy to use and achieves the main objective of the project.

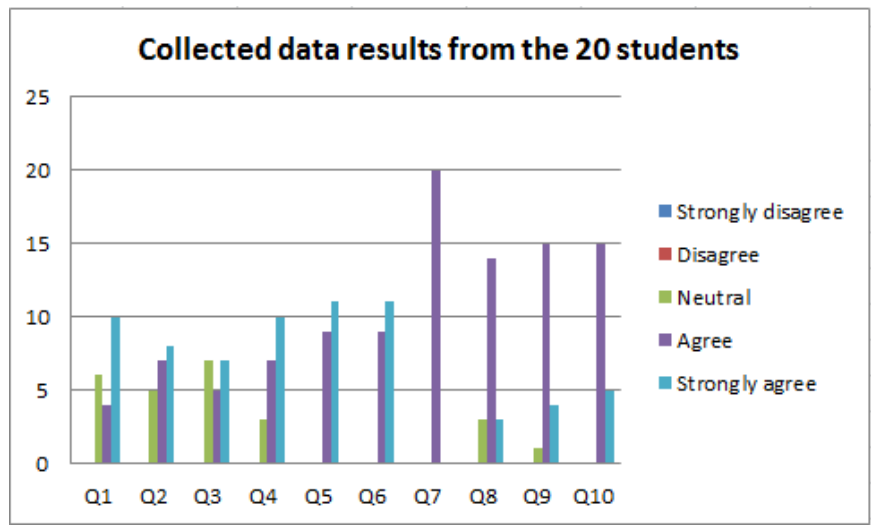

Figure 14: collected data results from the 20 students.

\section{Conclusion}

This work successfully designed and developed a smart application named "Jusoor" to bridge the gap and improve the communication process between the deaf, dumb People, and society. The proposed application provides the user with a dictionary that contains many vocabularies with videos explaining the way that the word is indicated, the most important sentences used in public places (markets, parks, restaurants, etc.), Emergency calls that enable recognizing the type assistance needed with the feature of locating the person which makes it easier to reach and provide the assistance, and service of communication with sign language experts. The proposed work was analyzed using the Unified
Modeling Language (UML), Firebase, XML and Java programming languages.

\section{REFERENCES}

[1]. Rastogi R, Mittal S and Agarwal S. A novel approach for communication among Blind, Deaf and Dumb people. In 2015 2nd International Conference on Computing for Sustainable Global Development (INDIACom), pp. 605-610.

[2]. Rajapandian B, Harini V, Raksha D and Sangeetha V. A novel approach as an AID for blind, deaf and dumb people. In 2017 Third International Conference on Sensing, Signal Processing and Security (ICSSS), pp. 403-408.

[3]. Agarwal S, Patel F, Chaturvedi P, Asha S and VIT C. A Novel Approach for Communication among Blind, Deaf and Dumb People. International Journal of Pure and Applied Mathematics, 2018, 118(24).

[4]. Rani H U, Deepak S, Dinesh S and Samuel F F. A Novel Approach for Communication among Blind, Deaf and Dumb.

[5]. Nashat D, Shoker A, Al-Swat F and Al-Ebailan R. An android application to aid uneducated deaf-dumb people. International Journal of Computer Science and Mobile Applications, 2014, 2(9): 1-8.

[6]. Kawale N, Hiranwar D and Bomewar M. An Android Messenger Application for Dumb and Deaf People. In National Conference on Advances in Engineering and Applied Science (NCAEAS).

[7]. Karmel A, Sharma A and Garg D. IoT based Assistive Device for Deaf, Dumb and Blind People. Procedia Computer Science, 2019, 165: 259-269.

[8]. Akthar S J, Yuvaraju P, Ramanjaneyulu M and Premkumar S. Survey on communication among blind, deaf and dumb people using a smart glove. 2018.

[9]. Rajendra A, Rajkumar N, Bhat S N, Suhas T and Joshi S P N. E-Learning Web Accessibility 
Framework for Deaf/Blind Kannada-Speaking Disabled People. Proceedings of ICRIC 2019. Springer, 2020, pp. 595-604.

[10]. El-Gayyar M M, Ibrahim A S and Wahed M E. Translation from Arabic speech to Arabic Sign Language based on cloud computing. Egyptian Informatics Journal, 2016, 17(3): 295-303.

[11]. Haron H, Samad H, Diah F M and Yusof H. ELEARNING APPROACH USING MOBILE APPS: MALAYSIAN SIGN LANGUAGE FOR DUMB AND DEAF. International Journal of Advanced Research in Technology and Innovation, 2019, 1(1): 1-7.

[12]. IhsanHuman. google play. https://play.google.com/store/apps/details?id=co m.techdevsa.ehsanensan\&hl=ar 1-5-2020].

[13]. Tawasoly. Arabnet. https://www.arabnet.me/english/startups/startu p-ar-20. 1-5-2020].

[14]. letmeHearyou. Google play. https://play.google.com/store/apps/details?id=co m.barmej.myapplication\&hl=ar. 2-5-2020].

[15]. AlTurjumanSL. App Store Preview. https://apps.apple.com/us/app/\%D8\%A7\%D9\% 84\%D8\%AA\%D8\%B1\%D8\%AC\%D9\%85\%D8 \%A7\%D9\%86-\%D9\%81\%D9\%8A\%D9\%84\%D8\%BA\%D8\%A9\%D8\%A7\%D9\%84\%D8\%A7\%D8\%B4\%D8\%A 7\%D8\%B1\%D8\%A9/id1146547215 . 3-5-2020].

[16]. Almarashdeh I and Alsmadi M K. How to make them use it? Citizens acceptance of Mgovernment. Applied Computing and Informatics.

[17]. Alsmadi M, Omar K, Noah S, Almarashdeh I, Al-Omari S, Sumari P, Al-Taweel S, Husain A, Al-Milli $\mathrm{N}$ and Alsmadi $\mathrm{M}$. Fish recognition based on robust features extraction from size and shape measurements using neural network. Information Technology Journal, 2009, 10(5): 427-434.

[18]. Alsmadi M, Omar K B and Noah S A. Back propagation algorithm: the best algorithm among the multi-layer perceptron algorithm.
International Journal of Computer Science and Network Security, 2009, 9(4): 378-383.

[19]. Alsmadi M k, Omar K B and Noah S A. Proposed method to decide the appropriate feature set for fish classification tasks using Artificial Neural Network and Decision Tree. IJCSNS 2009, 9(3): 297-301.

[20]. Alsmadi M K S, Omar K B, Noah S A and Almarashdah I. Fish recognition based on the combination between robust feature selection, image segmentation and geometrical parameter techniques using Artificial Neural Network and Decision Tree. arXiv preprint arXiv:0912.0986, 2009.

[21]. khalil Alsmadi M, Omar K B, Noah S A and Almarashdah I. Performance comparison of multi-layer perceptron (Back Propagation, Delta Rule and Perceptron) algorithms in neural networks. In 2009 IEEE International Advance Computing Conference, pp. 296-299.

[22]. Almarashdeh I A, Sahari N, Zin N A M and Alsmadi M. THE SUCCESS OF LEARNING MANAGEMENT SYSTEM AMONG DISTANCE LEARNERS IN MALAYSIAN UNIVERSITIES. Journal of Theoretical \& Applied Information Technology, 2010, 21(2).

[23]. Almrashdah I A, Sahari N, Zin N A H M and Alsmadi M. Instructors acceptance of distance learning management system. In Information Technology (ITSim), 2010 International Symposium in, pp. 1-6.

[24]. Almrashdah I A, Sahari N, Zin N A H M and Alsmadi M. Distance learners acceptance of learning management system. In Advanced Information Management and Service (IMS), 2010 6th International Conference on, pp. 304309.

[25]. Alsmadi M K, Omar K B and Noah S A. Fish recognition based on robust features extraction from size and shape measurements using backpropagation classifier. International Review on Computers and Software, 2010, 5(4): 489-494. 
[26]. Alsmadi M K, Omar K B, Noah S A and Almarashdeh I. Fish recognition based on robust features extraction from color texture measurements using back-propagation classifier. Journal of Theoritical and Applied Information Technology, 2010, 18(1).

[27]. Alsmadi M K, Omar K B, Noah S A and Almarashdeh I. Fish recognition based on robust features extraction from size and shape measurements using neural network. Journal of Computer Science, 2010, 6(10): 1088.

[28]. Almarashdeh I A, Sahari N, Zin N A M and Alsmadi M. Acceptance of learning management system: A comparison between distance learners and instructors. Advances in Information Sciences and Service Sciences, 2011, 3(5): 1-9.

[29]. ALMRASHDEH I A, SAHARI N, ZIN N A M and ALSMADI M. DISTANCE LEARNING MANAGEMENT SYSTEM REQIUREMENTS FROM STUDENT'S PERSPECTIVE. Journal of Theoretical \& Applied Information Technology, 2011, 24(1).

[30]. Almrashdeh I A, Sahari N, Zin N A M and Alsmadi M. Instructor's success measures of Learning Management System. In Electrical Engineering and Informatics (ICEEI), 2011 International Conference on, pp. 1-7.

[31]. Almrashdeh I A, Sahari N, Zin N A M and Alsmadi M. Requirement analysis for distance learning management system students in Malaysian universities. Journal of Theoretical and Applied Information Technology, 2011, 24(1): 17-27.

[32]. Alsmadi M, Omar K, Noah S and Almarashdeh I. A hybrid memetic algorithm with backpropagation classifier for fish classification based on robust features extraction from PLGF and shape measurements. Information Technology Journal, 2011, 10(5): 944-954.

[33]. Alsmadi M K, Omar K B and Noah S A. Fish classification based on robust features extraction from color signature using back- propagation classifier. Journal of Computer Science, 2011, 7(1): 52.

[34]. Alsmadi M, Omar K and Almarashdeh I. Fish Classification: Fish Classification Using Memetic Algorithms with Back Propagation Classifier. 2012.

[35]. Alsmadi M, Badawi U A and Reffat H E. A High Performance Protocol for Fault Tolerant Distributed Shared Memory (FaTP). Journal of Applied Sciences, 2013, 13: 790-799.

[36]. Alsmadi M, Badawi U A, Reffat H E, Qiang S, Chanjian F, Yuegang L and Peng S. Faults Diagnosis for Automotive Engine Based on Chinin. Journal of Applied Sciences, 2013, 13(23): 5632.

[37]. Badawi U A and Alsmadi M K S. A Hybrid Memetic Algorithm (Genetic Algorithm and Great Deluge Local Search) With BackPropagation Classifier for Fish Recognition International Journal of Computer Science Issues, 2013, 10(2): 348-356.

[38]. Thalji $\mathrm{Z}$ and Alsmadi M. Iris Recognition using robust algorithm for eyelid, eyelash and shadow avoiding. World Applied Sciences Journal, 2013, 25(6): 858-865.

[39]. Alsmadi M K. A hybrid firefly algorithm with fuzzy-C mean algorithm for MRI brain segmentation. American Journal of Applied Sciences, 2014, 11(9): 1676-1691.

[40]. Alsmadi M K, Badawi U A and Moharram H M. SERVER FAILURES ENABLED JAVASPACES SERVICE. Journal of Computer Science, 2014, 10(4): 671-679.

[41]. Badawi U A and Alsmadi M K. A GENERAL FISH CLASSIFICATION METHODOLOGY USING META-HEURISTIC ALGORITHM WITH BACK PROPAGATION CLASSIFIER. Journal of Theoretical \& Applied Information Technology, 2014, 66(3): 803-812.

[42]. Al Smadi A M, Alsmadi M K, Al Bazar H, Alrashed S and Al Smadi B S. Accessing Social Network Sites Using Work Smartphone for Face Recognition and Authentication. Research 
Journal of Applied Sciences, Engineering and Technology, 2015, 11(1): 56-62.

[43]. Alsmadi M K. MRI brain segmentation using a hybrid artificial bee colony algorithm with fuzzy-c mean algorithm. Journal of Applied Sciences, 2015, 15(1): 100.

[44]. HADDAD F, ALFARO J and ALSMADI M K. HOTELLING'S T ${ }^{2} \quad$ CHARTS USING WINSORIZED MODIFIED ONE STEP MESTIMATOR FOR INDIVIDUAL NON NORMAL DATA. Journal of Theoretical \& Applied Information Technology, 2015, 72(2): 215-226.

[45]. Almarashdeh I and Alsmadi M. Investigating the acceptance of technology in distance learning program. In 2016 International Conference on Information Science and Communications Technologies (ICISCT), 2-4 Nov. 2016, pp. 1-5.

[46]. Almarashdeh I and Alsmadi M. Heuristic evaluation of mobile government portal services: An experts' review. In Internet Technology and Secured Transactions (ICITST), 2016 11th International Conference for, pp. 427-431.

[47]. Alsmadi M. Facial recognition under expression variations. Int. Arab J. Inf. Technol., 2016, 13(1A): 133-141.

[48]. Alsmadi M K. Forecasting River Flow in the USA Using a Hybrid Metaheuristic Algorithm with Back-Propagation Algorithm. Scientific Journal of King Faisal University (Basic and Applied Sciences), 2017, 18(1): 13-24.

[49]. Alsmadi M K. Query-sensitive similarity measure for content-based image retrieval using meta-heuristic algorithm. Journal of King Saud University - Computer and Information Sciences, 2017.

[50]. Alsmadi M K. An efficient similarity measure for content based image retrieval using memetic algorithm. Egyptian Journal of Basic and Applied Sciences, 2017, 4(2): 112-122.
[51]. Alsmadi M K and Badawi U A. Pattern matching in Rotated Images Using Genetic Algorithm. Journal of King Abdulaziz University Computing and Information 2017, 5: 53 - 59.

[52]. Alsmadi M K, Hamed A Y, Badawi U A, Almarashdeh I, Salah A, Farag T H, Hassan W, Jaradat G, Alomari $\mathrm{Y} \mathrm{M}$ and Alsmadi $\mathrm{H}$ M. FACE IMAGE RECOGNITION BASED ON PARTIAL FACE MATCHING USING GENETIC ALGORITHM. SUST Journal of Engineering and Computer Sciences (JECS), 2017, 18(1): 51-61.

[53]. Farag $\mathrm{T} H$, Hassan $\mathrm{W}$ A, Ayad $\mathrm{H}$ A, AlBahussain A S, Badawi U A and Alsmadi M K. Extended Absolute Fuzzy Connectedness Segmentation Algorithm Utilizing Region and Boundary-Based Information. Arabian Journal for Science and Engineering, 2017: 1-11.

[54]. Aldaej R, Alfowzan L, Alhashem R, Alsmadi M K, Al-Marashdeh I, Badawi U A, Alshabanah M, Alrajhi D and Tayfour M. Analyzing, Designing and Implementing a Web-Based Auction online System. International Journal of Applied Engineering Research, 2018, 13(10): 8005-8013.

[55]. Almaimoni H, Altuwaijri N, Asiry F, Aldossary S, Alsmadi M, Al-Marashdeh I, Badawi U A, Alshabanah M and Alrajhi D. Developing and Implementing WEB-based Online Destination Information Management System for Tourism. International Journal of Applied Engineering Research, 2018, 13(10): 7541-7550.

[56]. Almarashdeh i, Alsmadi M K, Farag $T$, Albahussain A S, Badawi U A, Altuwaijri N, Almaimoni H, Asiry F, Alowaid S, Alshabanah M, Alrajhi D, Fraihet A A and Jaradat G. RealTime Elderly Healthcare Monitoring Expert System Using Wireless Sensor Network International Journal of Applied Engineering Research, 2018, 13(6): 3517-3523.

[57]. Almarashdeh I, Alsmadi M K, Jaradat G, Althunibat A, Albahussain S A, Qawqzeh Y, Badawi U A, Farag T and Eldaw K E. Looking 
Inside and Outside the System: Examining the Factors Influencing Distance Learners Satisfaction in Learning Management System Journal of Computer Science, 2018.

[58]. Almarashdeh I, Eldaw K E, AlSmadi M, Badawi U, Haddad F, Abdelkader O A, Jaradat G, Alkhaldi A and Qawqzeh Y. Search Convenience and Access Convenience: The Difference Between Website Shopping and Mobile Shopping. In International Conference on Soft Computing and Pattern Recognition, pp. 33-42.

[59]. Al-Marashdeh I, Jaradat G M, Ayob M, Abu-AlAish A and Alsmadi M. An Elite Pool-Based Big Bang-Big Crunch Metaheuristic for Data Clustering. Journal of Computer Science, 2018, 14(12): 1611-1626.

[60]. Alsmadi M K. Apparatus and method for lesions segmentation. 2018.

[61]. Alsmadi M K. Facial expression recognition. 2018.

[62]. Alsmadi M K. A hybrid Fuzzy C-Means and Neutrosophic for jaw lesions segmentation. Ain Shams Engineering Journal, 2018, 9(4): 697-706.

[63]. Alsmadi M K. Query-sensitive similarity measure for content-based image retrieval using meta-heuristic algorithm. Journal of King Saud University-Computer and Information Sciences, 2018, 30(3): 373-381.

[64]. Alsubaie N, Althaqafi N, Alradwan E, Al-Hazza F, Alsmadi M, Al-Marashdeh I, Badawi U A, Alshabanah M, Alrajhi D, Alsmadi S and Tayfour M. Analyzing and Implementing an Online Metro Reservation System. International Journal of Applied Engineering Research, 2018, 13(11): 9198-9206.

[65]. Daniyah Alkhaldi D A, Hajer Aldossary, Mutasem k. Alsmadi, Ibrahim Al-Marashdeh, Usama A Badawi, Muneerah Alshabanah, Daniah Alrajhi. Developing and Implementing Web-based Online University Facilities Reservation System. International Journal of
Applied Engineering Research, 2018, 13(9): 6700-6708.

[66]. Haddad F and Alsmadi M K. Improvement of The Hotelling's T2 Charts Using Robust Location Winsorized One Step M-Estimator (WMOM). Journal of Mathematics (ISSN 10162526), 2018, 50(1): 97-112.

[67]. Rasmi M, Alazzam M B, Alsmadi M K, Almarashdeh I A, Alkhasawneh R A and Alsmadi S. Healthcare professionals' acceptance Electronic Health Records system: Critical literature review (Jordan case study). International Journal of Healthcare Management, 2018: 1-13.

[68]. Abbas A A, Alzayer K, Alkhaldi A, Alsmadi M k, Alshabanah M, Alrajhi D, Almarashdeh I and Tayfour M. Analyzing and Implementinga System For Reporting, Follow Up and Resolving of Complaints. International Research Journal of Engineering and Technology, 2019, 6(1): 1833-1842.

[69]. Ahmed A O, Ahmed M E, Mekebbaty M M E, Osman A M, Mohamed A S, Alhaj G M and Shidwan O S. Impact of Change Characteristics in Planning for Future Professional Career. International Journal of Applied Engineering Research, 2019, 14(20): 3869-3878.

[70]. Aldossary S, Althawadi A, Almotairy M, Alsmadi M k, Alrajhi D, Alshabanah M, AlMarashdeh I, Tayfour M and Aljamaeen R. ANALYZING, DESIGNING AND IMPLEMENTING A WEB-BASED COMMAND CENTER SYSTEM. International Research Journal of Engineering and Technology, 2019, 6(1): 1008-1019.

[71]. Al-Ghamdi A, Al Harbi D, Alarfaj N, Al Hajri A, Almarashdeh I, Alsmadi M, Alshabanah M and Alrajhi D. Developing and Implementing a Web-Based Platform for Skills and Knowledge Exchange. Int J Sci Res Sci Technol, 2019, 6(3): 562-573.

[72]. Al-Ghamdi A, Harbi D A, Alarfaj N, Hajri B A, Almarashdeh I, Alsmadi M k, Alshabanah M 
and Alrajhi D. Developing and Implementing a Web-Based Platform for Skills and Knowledge Exchange. International Journal of Scientific Research in Science and Technology (IJSRST), 2019, 6(3).

[73]. Alhafi R, Almutairi S, Alsultan N, Alsmadi M K, Alshabanah M, Alrajhi D and Almarashdeh I. E-Payment and Transactions using QR Codes. 2019.

[74]. Alharbi S, Altamimi A, Al-Qahtani F, Aljofi B, Alsmadi M, Alshabanah M, Alrajhi D and Almarashdeh I. Analyzing and Implementing a Mobile Reminder System for Alzheimer's Patients. International Research Journal of Engineering and Technology, 2019, 6(2): 1-11.

[75]. Ali S A S, Eldaw K E H I, Alsmadi M K and Almarashdeh I. Determinants of deposit of commercial banks in Sudan: an empirical investigation (1970-2012). International Journal of Electronic Finance, 2019, 9(3): 230-255.

[76]. Almarashdeh I, Jaradat G, Abuhamdah A, Alsmadi M, Alazzam M B, Alkhasawneh R and Awawdeh I. The Difference Between Shopping Online Using Mobile Apps and Website Shopping: A Case Study of Service Convenience. International Journal of Computer Information Systems and Industrial Management Applications, 2019, 11: 151-160.

[77]. Al-Omairi D S, AlNasheri W H, Al-Qarni W Y, Almarashdeh I, Alsmadi M k, Alshabanah M and Alrajhi D. Developing and Implementing A Web-Based Recycling System For Protecting The Green Environment. International Journal of Software Engineering and Applications, 2019, 10(3): 59-72.

[78]. Alomari E, Alshammry M, Alhamil S, Alsmadi M, Alshabanah M, Alrajhi D, Almarashdeh I and Eljawad L. Analyzing, Designing and Implementing a Consulting Company for Management Information Systems. International Research Journal of Engineering and Technology, 2019, 6(2): 422-432.
[79]. Alomari E, Alshammry M, Alhamil S, Alsmadi M k, Alshabanah M, Alrajhi D, Almarashdeh I and Eljawad L. Analyzing, Designing and Implementing a Consulting Company for Management Information Systems. International Research Journal of Engineering and Technology 2019, 6(2): 422-432.

[80]. Al-Smadi A M, Alsmadi M K, Baareh A, Almarashdeh I, Abouelmagd $\mathrm{H}$ and Ahmed O S S. Emergent situations for smart cities: a survey. International Journal of Electrical \& Computer Engineering (2088-8708), 2019, 9(6): 47774787.

[81]. Alsmadi M K. Hybrid Genetic Algorithm with Tabu Search with Back-Propagation Algorithm for Fish Classification: Determining the Appropriate Feature Set. International Journal of Applied Engineering Research, 2019, 14(23): 4387-4396.

[82]. Alsmadi M K, Tayfour M, Alkhasawneh R A, Badawi U, Almarashdeh I and Haddad F. Robust feature extraction methods for general fish classification. International Journal of Electrical \& Computer Engineering (20888708), 2019, 9(6): 5192-5204.

[83]. Al-Theeb R, Al-Tami H, Al-Johani H, AlMutairi A, Al-Marashdeh I, Alsmadi M K, Alshabanah $\mathrm{M}$ and Alrajhi D. Developing and Implementing A System for Shipping Companies Comparison. IJSRST 2019, 6(4).

[84]. Alzamel H, Alshabanah $\mathrm{M}$ and Alsmadi $\mathrm{M}$. Point of Sale (POS) Network with Embedded Fingerprint Biometric Authentication. International Journal of Scientific Research in Science and Technology (IJSRST), 2019, 6(5): 95-111.

[85]. Eljawad L, Aljamaeen R, Alsmadi M K, AlMarashdeh I, Abouelmagd H, Alsmadi S, Haddad F, Alkhasawneh R A, Alzughoul M and Alazzam M B. Arabic Voice Recognition Using Fuzzy Logic and Neural Network. International Journal of Applied Engineering Research, 2019, 14(3): 651-662. 
[86]. Haddad F, Alsmadi M K, Badawi U, Farag T, Alkhasawneh R, Almarashdeh I and Hassan W. Bivariate modified hotelling's $\mathrm{T}^{2}$ charts using bootstrap data. International Journal of Electrical \& Computer Engineering (20888708), 2019, 9(6): 4721-4727.

[87]. Mohammed A S S, Alhaj G M, Osman A M and Ahmed A O. The Effectiveness of the Decision Making of the Saudi Arabian Universities Applied Colleges' Faculties Boards and Departmental Councils. International Journal of Applied Engineering Research, 2019, 14(23): 4221-4227.

[88]. Osman A M, Ahmed A O, Eltahir M N, Mohamed A S, Shidwan O S and Ghada M. Investigating the Causes of inflation in Saudi Arabia: An Application of Autoregressive Distributed Lag (ARDL) Model. International Journal of Applied Engineering Research, 2019, 14(21): 3980-3986.

[89]. Qawqzeh Y K, Otoom M M, Al-Fayez F, Almarashdeh I, Alsmadi $\mathrm{M}$ and Jaradat G. A Proposed Decision Tree Classifier for Atherosclerosis Prediction and Classification. IJCSNS, 2019, 19(12): 197.

[90]. Sheikh R A, Al-Assami R, Albahr M, Suhaibani M A, Alsmadi M k, Alshabanah M, Alrajhi D, Al-Marashdeh I, Alsmadi S, Abouelmagd $\mathrm{H}$ and Tayfour M. Developing and Implementing a Barcode Based Student Attendance System. International Research Journal of Engineering and Technology, 2019, 6(1): 497-506.

[91]. Alsmadi M K. Content-Based Image Retrieval Using Color, Shape and Texture Descriptors and Features. Arabian Journal for Science and Engineering, 2020: 1-14.

[92]. Alzaqebah M A, Alrefai N, Ahmed E, Jawarneh $S$ and Alsmadi M. Neighborhood search methods with Moth Optimization algorithm as a wrapper method for feature selection problems. International Journal of Electrical \& Computer Engineering, 2020, 10(4).
[93]. Qawqzeh Y K, Jaradat G, AlYousef A, AbuHamdah A, Almarashdeh I, Alsmadi M, Tayfour M, Shaker K and Haddad F. Applying the Big Bang-Big Crunch Metaheuristic to Large-sized Operational Problems. International Journal of Electrical and Computer Engineering, 2020, 10(3): 2484-2502.

[94]. Karim S, Liawatimena S, Trisetyarso A, Abbas B $S$ and Suparta W. Automating functional and structural software size measurement based on $\mathrm{XML}$ structure of UML sequence diagram. In Cybernetics and Computational Intelligence (CyberneticsCom), 2017 IEEE International Conference on, pp. 24-28.

[95]. Dennis A, Wixom B H and Tegarden D. Systems analysis and design: An object-oriented approach with UML. 2015.

[96]. Al-Omairi D, AlNasheri W, Al-Qarni W, Almarashdeh I, Alsmadi M, Alshabanah M and Alrajhi D. Developing and Implementing a Web-Based Recycling System for Protecting the Green Environment. International Journal of Software Engineering \& Applications (IJSEA), 2019, 10(3).

[97]. Al Hayek F, Khelaif M, Shaikh Z, Alshammari $\mathrm{H}$, Alshabanah M, Alrajhi D, Alsmadi M and Almarashdeh I. Developing and Implementing a Web-Based educational platform for Children with Special Needs. International Journal of Scientific Research in Science and Technology, 2020.

[98]. Alkhalfan A S, Altheeb Z W, Alshamsi N A, Alothman H W, Almarashdeh I, Alshabanah M, Alrajhi D and Alsmadi M. Designing and Developing of E-Commerce Website for Unused New Goods Shopping. International Journal of Scientific Research in Science and Technology (IJSRST), 2020, 7(2): 215-225.

[99]. Alqahtani A, Alshehri B, Alqahtani M, Abumelha M, Alshabanah M, Alrajhi D, Alsmadi $\mathrm{M}$ and Almarashdeh I. Developing and Implementing a Website for Sports Clubs. International Journal of Scientific Research in 
Science and Technology (IJSRST), 2020, 7(2): 135-146.

[100]. Alqahtani M, Bashunaym R, Alotaibi N, Alkhaldi R, Alshabanah M, Alrajhi D, Alsmadi $\mathrm{M}$ and Almarashdeh I. Developing a Smart Nursery Application for Monitoring and Babies Care. International Journal of Scientific Research in Science and Technology, 2020.

[101]. Alqarni N, Alqahtani S, Alhumaidi S A, Almutairi I, Alshabanah M, Alrajhi D, Alsmadi $\mathrm{M}$ and Almarashdeh I. Developing a Platform for Chronic Diseases Awareness. International Journal of Scientific Research in Science and Technology, 2020.

[102]. Faraj A, Alzahrani S, Almumtin R, Alrajhi D, Alshyban S, Alshabanah M, Alsmadi M and Almarashdeh I. Developing and Implementing an Online Learning Platform for Children with Autism. International Journal of Scientific Research in Science and Technology, 2020.

\section{Cite this article as :}

Fatimah Mohammed Al Nas, Sajidah Hassan Sahwan, Fatimah Saeed Alali, Muneerah Alshabanah, Daniah Alrajhi, Mutasem K. Alsmadi, Ibrahim Almarashdeh, Mohammed Fahed Tayfour, "Designing and Developing A Smart Application for Improving the Communication Between the Deaf, Dumb People and Society", International Journal of Scientific Research in Science and Technology (IJSRST), Online ISSN : 2395-602X, Print ISSN : 2395-6011, Volume 7 Issue 3, pp. 285-297, May-June 2020. Available at doi : https://doi.org/10.32628/IJSRST207352

Journal URL : http://ijsrst.com/IJSRST207352 